\title{
Питання психології
}

УДК $159.947 .2: 355.133 .4$

DOI: $10.33099 / 2617-6858-20-54-1-193-199$

Черевичний С. В., ад'юнкт кафедри суспільних наук НУОУ імені Івана Черняховського

https://orcid.org/0000-0001-9691-5261

\section{ПСИХОЛОГІЧНІ ЧИННИКИ У ПРИЙНЯТТІ РІШЕННЯ КОМАНДИРОМ}

В статті розглянуто особистість командира в бойовій обстановиі, розкрито індивідуальнопсихологічні властивості, які мають бути притаманні командиру, що приймає рімення. Визначено психологічні чинники, що впливають на прийняття рішення командиром, врахування яких обумовлюватиме ефективність реалізайї иџього рімення в бойовій обстановиі та в ситуаиії невизначеності.

Ключові слова: командир; рімення; психологічні чинники; пильність; невизначеність; новизна; аналіз обстановки; пізнавальна діяльність .

Постановка проблеми. Психологія прийняття рішення і іï важлива складова частина - пізнавальна діяльність командира в бою - включає в себе цілий комплекс пізнавальних психічних процесів, за допомогою яких здійснюється сприйняття бойової обстановки, відпрацювання рішення на бойові дії і відповідні їм накази, команди, розпорядження. Але особливої уваги це питання набуло в сучасному світі у зв'язку з розвитком військово-технічного прогресу. 3'явилась необхідність не лише виявити механізм мислення командира, але й знайти шляхи підвищення ефективності всієї його пізнавальної діяльності в процесі підготовки і прийнятті рішення в умовах складності та невизначеності сучасного бою. Постало завдання всебічно розглянути питання психології рішення командира.

\section{Аналіз останніх досліджень і} публікацій.

Пізнавальна діяльність командира в бою, його мислення, пам'ять, уява при оцінці бойової обстановки, прийнятті рішення на бій i в ході бою цікавили багатьох військових начальників та теоретиків як минулого, серед яких можна назвати Наполеона, Клаузевіца, Ліддел Гарта, Суворова, Драгомирова так i теоретиків сучасності В. Осьодло, В. Стасюк, М. Цюрупа, В. Невмержицький та інших. На думку Б. Теплова, від командира в ході бою вимагають дві якості - добре розвинуті розумові здібності і сильна воля [5]. В свою чергу М. Драгомиров зазначає, що війна, справа значною мірою більш вольова ніж розумова. Багато дослідників притримуються думки, згідно якої, функцією розуму $є$ створення планів, а функцією волі - їх виконання. На наш погляд, виконання плану вимагає розуму не менше, аніж волі і тісно пов'язане 3 його відпрацюванням та $є$ важливою особливістю інтелектуальної праці командира.

Метою статті $\epsilon$ розкриття індивідуально-психологічних властивостей, які мають бути притаманні командиру, що приймає рішення та визначення психологічних чинників, що впливають на прийняття рішення командиром.

Методи дослідження. Для досягнення мети нами були використані методи аналізу, порівняння, узагальнення та анкетування.

Виклад основного матеріалу. Складність обстановки і швидкість ії зміни, висока маневреність військ і не достатня кількість даних про обстановку, збільшений об'єм інформації і обмежений час на іiі обробку - все це створює для командира умови невизначеності, і обумовлює пошук шляхів удосконалення пізнавальної діяльності. Актуальними в пізнавальній діяльності $\epsilon$ побудова мисленевої моделі майбутнього бою при прийнятті рішення, евристиці командира, передбаченні в бою. Своєчасне і обгрунтоване рішення - результат цілеспрямованого мислення командира i важливий фактор досягнення перемоги в бою. Різко зростає роль рішення і всієї пізнавальної діяльності командира в сучасному бою, іiі вплив на хід та результат бою визначається такими об'єктивними причинами як зміна характеру і сутності загальновійськового бою, ускладнення керівництва i вміст інтелектуальної діяльності командира в динаміці бойових дій [4].

Сучасний бій не без підстав називають боротьбою інтелектів. Багатогранність засобів, форм та методів ведення бойових дій пред’являє завищені вимоги до об'єму 


\section{Питання психології}

знань, професійної майстерності, вольових якостей і мисленової діяльності командирів. При більшості рівних умов перемогу у бою або війні отримає той, хто краще оцінить обстановку, швидше прийме оптимальне рішення, повністю використає можливості озброєння та техніки, перехитрить противника, застосує неочікуваний тактичний прийом. В основі цього лежить цілеспрямована, чітко організована творча пізнавальна діяльність командира. Оптимальне рішення командира - це не тільки основа управління військами, але й мірило ефективності його пізнавальної діяльності [4].

Основними факторами, що ускладнюють прийняття рішення та управління підрозділами в умовах невизначеності є:

- нові бойові засоби, які різко підняли вогневі можливості військ;

- нові засоби бойових дій як із застосуванням так і без застосування ядерної зброї;

- поява командирів 3 неординарним критичним та практичним мисленням;

- нові технічні засоби управління, які значно збільшили психофізіологічні можливості командирів.

Водночас, до основних характерних рис сучасного керівництва військами можемо віднести:

- підвищення відповідальності командирів за прийняття рішення, зростає роль оптимальності цих рішень, ступені їх розрахункової обгрунтованості;

- вирішальне значення оперативності керівництва військами, жорстка економія часу командирами при виконанні кожної функції керівництва;

- гранична конкретність планування бойових дій;

- сувора регламентація об'єму інформації про обстановку, що надходить командиру у вигляді наказів та розпоряджень;

- висока інтенсивність діяльності командира при прийнятті рішення;

- $\quad$ ріст ролі передбачення в діяльності командира при прийнятті рішення за допомогою методів математичного моделювання та прогнозування;

- висока маневреність і рухливість пунктів управління;
- вирішальна роль моральнопсихологічного стану підрозділу;

- зростання ролі творчого мислення командирів.

Досліджуючи розум і волю командира психологи подекуди розділяють їх на дві різні здібності. Разом 3 тим, 3 позиції Аристотеля істинним двигуном вольової дії людини є "розум i прагнення" або ж “розумне прагнення”. "Розум не приводить в рух прагнення”, але “дві здібності - розум і прагнення - обумовлюють рух" [5, с. 262].

Майже завжди розум командира працює в стихії небезпеки. Прийнято вважати, що в стані небезпеки і страху, якість продуктивної розумової роботи знижується. На думку Клаузевіца, в командира все повинно протікати навпаки: небезпека i відповідальність повинна загострювати роботу розуму. Також вважається, що стан смертельної небезпеки будучи невіддільним від бойової обстановки, неминуче викликає емоцію страху (пригнічення). Повна перемога над страхом може сама по собі дати лише нормальний психічний стан. Водночас "нормального" як і “спокійного" стану в бою не буває і бути не може [5, с. 266].

Питання, яке постає в цьому контексті полягає не в тому, переживає чи не переживає командир в бою емоцію страху, а в тому, як він іiі рефлексує. Емоція страху може як подавлювати командира так i викликати позитивний стан бойового збудження. Остання $є$ необхідним супутником воєнного покликання й психічної стійкості [3]. Якщо атмосфера небезпеки викликаючи гнітючу емоцію страху в одного командира знижує розумову діяльність, то в другого - вона створює позитивну емоцію "бойового збудження" посилюючи й загострюючи роботу розуму. Активізація психічних сил командира, загострення розумової діяльності в атмосфері небезпеки - це саме та риса, яка характеризує добре підготовлених командирів. Наші спостереження показують, що існують й інші типи командирів у яких простежується своєрідна “економія психічних сил". Такі командири вміють в гострі моменти здійснювати максимальну мобілізацію своїх можливостей, хоча в повсякденному житті видаються в'ялими й малоактивними.

Вагомим доробком рішення командира 


\section{Питання психології}

$\epsilon$ аналіз обстановки. Без усвідомлення обстановки, вести мову щодо планування чи прогнозування недоречно. Аналітичний розум командира, перш ніж прийняти рішення, має розібратися в намірах противника, можливостях своїх сил, оцінити місцевість. Перша особливість інтелектуальної праці командира - значна складність матеріалу, яка підлягає аналізу. Друга, не менш характерна особливість, простота, чіткість, визначеність продуктів праці (планів, комбінацій, рішень), до яких приходить командир. Достеменно відомо, що чим простіший й грунтовніший план бою, тим він при інших рівних обставинах $€$ кращим, оскільки “... простота уявлень... складає самий корінь ефективного ведення війни" [5, с. 273].

Для інтелектуальної праці командира $\epsilon$ типовими дві особливості: а) надмірна складність вихідного матеріалу; б) простота і ясність кінцевого результату. На початку аналіз складного матеріалу, в підсумку синтез, який дозволяє отримати прості відповідні положення. Перетворення складного в просте - головна інтелектуальна риса командира $[3,5]$.

Ситуація бою дозволяє виокремити три типи командирів: перший - врівноважений, який спочатку спостерігає, обережно аналізує й критикує задля того, щоб потім плідно і впевнено діяти; другий - командираналітик, який занурившись в деталі, внаслідок бажання чітко бачити всі елементи, забуває приступити до реалізації самого рішення, оскільки скований надмірним ризиком; третій - надмірно синтетичний командир, який по своїй суті активний, справу обговорює стільки, скільки потрібно, щоб прийняти рішення над яким працював, незважаючи на попередні невдачі здатен знову приступати до справи.

Дані, на які опирається командир, характеризуються не лише багатоманітністю, але й складністю та заплутаністю взаємовідношень. Вони, окрім того, ніколи не бувають повністю відомими, досить швидкоплинні. Виходячи 3 цього, рішення командира тісно пов'язано 3 ризиком: без ризику діяльність командира неможлива. Це в свою чергу вимагає від нього добре розвинутих цілого ряду якостей. Серед яких: а) здатність до ризику; б) сміливість думки; в) мужність; г) рішучість [7]. Зупинимось на окремих із них більш детальніше. На думку Клаузевіца, рішучість, це здатність, що нівелює муки сумніву, прояви амбівалентності [2]. Рішучість - це мужність, яка дозволяє командиру діяти не дивлячись на відсутність недостовірних даних. Виходячи 3 окресленого контексту, командиром можуть бути лише ті військовослужбовці, в яких обережність і сміливість думки утворюють єдність, яку за Б.Тепловим прийнято називати "обережною сміливістю”. Це положення не слід трактувати в контексті певної "золотої середини”, як деяке середнє явище між сміливістю і обережністю. Не слід також вважати, що в деяких командирів в ситуації бою, сміливість немовби знижується, слабшає, стримується обережністю. Скоріш навпаки: обережність, висока критичність думки дають можливість приймати i втілювати такі сміливі рішення, які поза цим $\epsilon$ немислимими.

Поєднання сміливості та обережності створює в командира впевненість, яка $\epsilon$ необхідною запорукою перемоги. Командир, беручи до уваги всі можливі варіанти розвитку справи, навіть самі найгірші, готуючись до неочікуваних подій, здатен спокійно і впевнено дивитись вперед. Водночас, нічим необгрунтована самовпевненість командира знищує його обережність, а втрата останньої знищує здорову впевненість в собі.

Резюмуючи вищезазначене, варто наголосити, що дії командира в бою не можуть бути просто “вільними акціями”. Вони повинні бути реакцією на наміри і дії противника, зберігаючи при цьому ініціативність й велику силу вольового натиску. На війні командир повинен відмовитися, коли це потрібно, від своїх планів, замінивши їх новими. Твердість, стійкість й особливо завзятість командира відносно своїх планів може проявлятися порізному й знаходити вираження у: 1) впевненому відстоюванні своїх планів перед вищестоящими інстанціями, перед думкою армії; 2) у боротьбі 3 природою; 3) в стійкості під час бою; 4) в не підпорядкуванні волі противника, незважаючи на всю силу його натиску.

Завзяте прагнення командира дотримуватись раз і назавжди прийнятого плану не повинно виходити із слабкої 


\section{Питання психології}

здібності щодо складання самих планів. Людина, якій 3 великими зусиллями вдається скласти один “гарний” план, природно, прагнутиме дотримуватись цього плану, не тому, що він найкращий, а перш за все тому, що він вже $\epsilon$, а інший ще слід скласти. Значна майстерність в складанні планів - необхідна умова гнучкого відношення до своїх планів.

Завзятість, яка базується на нарцисизмі, надмірній впевненості в собі, відсутності мужності для визнання своєї помилки - це вже не завзятість, а впертість (в негативному розумінні цього слова), тобто властивість, яка для командира $\epsilon$ в певній мірі небезпечною. Справжня завзятість командира виражається в тому, що план на бій відстоюється і впроваджується в життя, наскільки б це не було складно, до тих пір, поки він $\epsilon$ найкращим [5].

На процес прийняття рішення командиром в умовах бою суттєвий вплив здійснюють ряд психологічних чинників. Для з'ясування головних чинників, які заважають прийняти рішення командирам, нами було проведено анкетування. Вибірку склали офіцери у військовому званні майор, підполковник, що обіймали командні посади до вступу на навчання Національного університету оборони Імені Івана Черняховського. Кількість респондентів становила 171 офіцер.

Зокрема, командирам пропонували із ряду чинників (новизна, раптовість, невизначеність, небезпека, дефіцит часу, збільшення темпу дій) вибрати три тих, що найбільш негативно впливають на прийняття ними рішення. Результати анкетування показали, що головним чинником, який заважає прийняти рішення командирові $є$ невизначеність $(77 \%)$. На другому місці офіцери визначили дефіцит часу (73\%), а третє місце віддали раптовості (40\%). Небезпека (30\%), новизна (29\%) та збільшення темпу дій (22\%) відповідно є менш значущими подразниками у прийнятті рішення.

Розглянемо ці основні психологічні чинники більш детально, щоб з'ясувати їх вплив на прийняття рішення командиром.

1. Чинник небезпеки (усвідомлена загроза життю, здоров'ю чи благополуччю). Чинник небезпеки є основним (первинним), який визначає психологічну специфіку бойових ситуацій, але він не завжди зумовлює поведінку i психічний стан командира. Як показує досвід антитерористичної операції, інколи об'єктивно небезпека існує, але суб' єктивно вона може не сприйматися, або ж навпаки. Небезпека досить часто породжує панічні стани. В.М.Бехтєрев характеризує паніку наступним чином: "Хто переживав разом 3 іншими паніку, той знає, що це не проста боязкість, яку можна подолати в собі свідомістю обов'язку чи внаслідок переконання. $\mathrm{Hi}$, це афект, що розвивається при певному несподіваному враженні загрозливого характеру 3 незвичайною швидкістю... Це щось таке, що охоплює майже раптово цілу групу осіб відчуттям неминучої небезпеки, проти якої абсолютно безсиле переконання й яке отримує пояснення лише в навіюванні цієї ідеї чи шляхом несподіваних зорових вражень (раптовий обстріл, поява ворожих військ) або шляхом слова, зумисно чи випадково кинутого в натовп” [1, с. 144]. У такому стані війська нездатні виконати завдання, абсолютно некеровані, вони стають легкою здобиччю для противника. Чим раптовішою $\epsilon$ небезпека, тим більшою видається вона ворогу i першою думкою раптово атакованого ворога $\epsilon$ не опір, а втеча. Первинність впливу чинника небезпеки на процес прийняття рішення командиром зумовлюється підсиленням дії інших чинників (раптовість, невизначеність, новизна). Залежно від сприйняття на особистому рівні характеру й величини небезпеки регулюватиметься i поведінка командира бою. Навчившись розрізняти небезпеку, прогнозувати ii результати, командир значно підвищить боєздатність i боєготовність ввірених йому підрозділів і частин. Для цього чинник небезпеки необхідно моделювати на заняттях в процесі бойової підготовки [6].

2. Чинник раптовості характеризується непрогнозованою зміною обстановки в ході виконання завдання, що вимагає коректування плану дій. Готуючись до бою командир планує свою діяльність, намагаючись врахувати можливі варіанти розвитку бойової обстановки. Реалізовуючи цю програму командир прагне досягти поставленої мети. Якщо при цьому виникають якісь раніше не прогнозовані зміни умов діяльності відбувається коректування програми, кінцева ж мета 


\section{Питання психології}

діяльності залишається незмінною. Водночас можуть відбутися зміни, яких командир не передбачав. У такому разі мова йде про чинник раптовості. Чим вище величина відмінності реальної від очікуваної зміни обстановки, тим вище ступінь раптовості. При цьому командир змушений відмовлятися від старого, продуманого плану діяльності, і складати новий, а іноді вимушений змінювати не лише план, але й мету діяльності. Відчутний удар по психіці може бути завданий командирові саме раптовістю [6].

Водночас, не всі командири однаково реагують на раптовість. Умовно можемо виділити три основних типи поведінки в умовах дії чинника раптовості:

1) командир швидко переключає увагу, визначає нові цілі й докладає зусилля щодо ї реалізації. Така реакція вважається найбільш бажаною;

б) командир, усвідомлюючи раптову зміну обстановки, продовжує діяти за старою програмою;

в) командир припиняє здійснювати свідому діяльність на якийсь проміжок часу. Два останні типи реакції призводять, як правило, до поразки в бою.

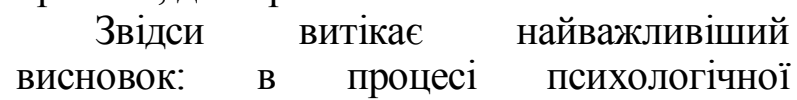
підготовки командири всіх рівнів повинні навчитися тому, як необхідно діяти в умовах раптовості.

3. Чинник невизначеності. Під ним ми розуміємо відсутність, або суперечність інформації про зміст чи умови виконання бойового завдання, про противника i характер його дій.

Невизначеність прямо пропорційно впливає на стан психічної напруженості особового складу. Цей стан неоднозначно позначається на стійкості й надійності діяльності. Якщо психічна напруженість надмірна, то іï негативний вплив виявляється в двох формах: перша “ступор”, при якій знижується або повністю припиняється діяльність командира, порушується координація рухів, погіршується або повністю відключається пам'ять; друга - неврегульована активність, яка характеризується появою некерованої, неосмисленої активності. В той же час помірний стан напруженості здійснює благополучний вплив на поведінку командира. Він активізує всі його психічні функції, сприяє скороченню часу адаптації.

Чинник невизначеності повинен часто супроводжувати процес прийняття рішення командиром. Навчившись в процесі бойової підготовки приймати рішення в умовах дії даного чинника командир легше справлятиметься з ним в ході бою.

Негативний вплив невизначеності може зменшуватися, якщо командир володіє прийомами контролю емоційної напруженості, оскільки вони є складовою частиною спеціальних методів психологічної підготовки.

4. Чинник новизни сигналізує командиру про наявність невідомих йому елементів в умовах виконання бойового завдання. Новизна залежить від досвіду й знань командира. Негативний вплив чинника новизни в умовах бою частково можна зменшити якщо в процесі психологічної підготовки командир вивчатиме реальний досвід дій в різних ситуаціях бою. Такі заняття повинні мати вид детального розбору бойової ситуації, супроводжуватись аналізом допущених помилок й прогнозом можливих варіантів розвитку обстановки.

5. Чинник збільшення темпу дій має місце в тому випадку, якщо різко скорочується час на виконання необхідних для досягнення мети дій. Такі ситуації в бою виникають часто. Тренувати прийняття рішення командиром в умовах скорочення часу на виконання нормативів бойової підготовки, добиватися автоматизації їх дій - важлива передумова успіху в бою.

6. Чинник дефіциту часу виникає в умовах, коли успішне виконання завдання неможливо простим збільшенням темпу дій. За таких умов необхідно змінити структуру діяльності. Уміти діяти нестандартно, творчо - важлива передумова досягнення успіху в бою. Іншими словами дефіцит часу вимагає від командира швидкої перебудови всієї структури бойової діяльності: визначення найбільш важливих в даних обставинах операцій, дій і відкидання другорядних. В умовах дефіциту часу не просто збільшується темп виконуваних дій, але й змінюється їх послідовність.

На процес прийняття рішення окрім описаних чинників вплив здійснюють й інші. Серед них: а) фізичні; б) метеорологічні; в) радіаційні; г) барометричні; д) механічні; ж) хімічні [7]. Дії даних чинників на психологічну стійкість командира в процесі прийняття 


\section{Питання психології}

рішення не слід зменшувати. Так, хімічні чинники безпосередньо впливають на нервову систему людини викликаючи різкі емоційні зрушення. Надлишок кисню викликає емоційне збудження. Окрім цього, слід наголосити, що особливості емоційних зрушень і їх характер залежать перш за все від інтенсивності зазначених чинників.

Висновки та перспективи подальших досліджень. Провівши аналіз найбільш істотних психологічних чинників бою, які здійснюють вплив на процес прийняття рішення командиром, вважаємо, що їх слід моделювати на заняттях 3 бойової підготовки. Кожен прийом, що створює ситуацію, можливу в бою, моделює не один, а декілька психологічних чинників бою. При цьому один 3 них буде, як правило, більш виражений, аніж інші.
Опинившись в бойовій обстановці, на перших порах, командир здатний відчувати розгубленість. Потрібен певний час, впродовж якого долаючи боязнь і страх, командир навчиться розрізняти такі ситуації, прогнозувати їх розвиток i наслідки, регулюючи свою поведінку. Це період можна значно скоротити за умови систематичної і головне свідомої роботи по оволодінню військово-професійною діяльністю в умовах дії модельованих психологічних чинників бою.

Подальші дослідження у прийнятті рішення командирами ми вбачаємо в детальному вивченні головного чинника який негативно впливає на прийняття рішення і постійно супроводжує командира - це невизначеність.

\section{Список використаних джерел}

1. Бехтерев В.М. Внушение и его роль в общественной жизни. СПб., 1908. 144 с.

2. Клаузевиц К. О войне. Издательский дом “PRESS” T.1. 1997.С.134-147.

3. Осьодло В.І. Психологія професійного становлення офіцера. Монографія. Київ. “Золоті ворота". 2012. $463 \mathrm{c.}$

4. Рябчук В.Д., Ковалев. М.В. Психология решения командира. Воениздат. 1976. 206 с.

5. Теплов Б. М. Ум полководца. Проблемы индивидуальных различий. М. АПН РСФСР. 1961. С. $252-344$.

6. Хміляр О.Ф. Психологічна підготовка солдата і офіцера. Вісник національного університету оборони Украӥни. 3б-к. наук. пращь. К. НУОУ. 2013. Вип. 1 (32). С.317-322.

7. Хміляр О.Ф. Субєктна активність командира в прийнятті ризикованого рішення. Матеріали Третьої Всеармійської науково-практичної конферениї “Актуальні проблеми становлення особистості професіонала в ризиконебезпечних професіях”. К. НУОУ. 2011. С.352-356.

\section{References}

1. Bekhterev V.M. Vnushenye y eho rol v obshchestvennoi zhyzny. SPb., 1908. 144 s.

2. Klauzevyts K. O voine. Yzdatelskyi dom "PRESS" T.1. 1997.S.134-147.

3. Osodlo V.I. Psykholohiia profesiinoho stanovlennia ofitsera. Monohrafiia. Kyiv. "Zoloti vorota". 2012. $463 \mathrm{~s}$.

4. Riabchuk V.D., Kovalev. M.V. Psykholohyia reshenyia komandyra. Voenyzdat. 1976. 206 s.

5. Teplov B. M. Um polkovodtsa. Problemы yndyvydualnыkh razlychyi. M. APN RSFSR. 1961. S. 252-344.

6. Khmiliar O.F. Psykholohichna pidhotovka soldata i ofitsera. Visnyk natsionalnoho universytetu oborony Ukrainy. Zb-k. nauk. prats. K. NUOU. 2013. Vyp. 1 (32). S.317-322.

7. Khmiliar O.F. Subiektna aktyvnist komandyra v pryiniatti ryzykovanoho rishennia. Materialy Tretoi Vsearmiiskoi naukovo-praktychnoi konferentsii "Aktualni problemy stanovlennia osobystosti profesionala $\mathrm{V}$ ryzykonebezpechnykh profesiiakh”. K. NUOU. 2011. S.352-356.

\section{Резюме}

Черевичный С., адъюнкт кафедры общественных наук НУОУ имени Ивана Черняховского

\section{ПСИХОЛОГИЧЕСКИЕ ФАКТОРЫ В ПРИНЯТИИ РЕШЕНИЯ КОМАНДИРОМ}

В статье рассмотрены личность командира в боевой обстановке, раскрыто индивидуальнопсихологические свойства, которые должны быть присущи командиру, что принимает решение. Определены факторы, влияющие на принятие решения командиром, учет которых предопределит эффективность реализации этого решения в боевой обстановке и в ситуации неопределенности.

Ключевые слова: командир; решения; факторы; бдительность; неопределенность; новизна; анализ обстановки; познавательная деятельность. 


\section{Питання психології}

\section{Summary \\ Cherevychnyi S., Adjunct of the Department \\ of Social Sciences of National Defence \\ University of Ukraine named after Ivan Chernyakhovskyi \\ PSYCHOLOGICAL FACTORS IN DECISION-MAKING COMMANDER}

Introduction. The article examines the personality of the commander in a combat setting, reveals the individual-psychological properties that must be commander in the decision-maker. The psychological factors influencing the decision-making of the commander have been determined, which consideration will determine the effectiveness of the implementation of this decision in the combat situation and in the situation of uncertainty.

Purpose. Disclosure of the individual-psychological properties that must be commander in the decisionmaker and the determination of the psychological factors that influence the decision-making of the commander.

Methods. We have used methods of analysis, comparison, generalization and questionnaire to achieve our goal. In order to find out the main factors that hinder the decision of the commanders, we conducted a survey. The number of respondents was 171 officers.

Results. The commanders were offered to select the three factors that most negatively influence their decision-making from a number of factors (novelty, suddenness, uncertainty, danger, time deficit, increased pace of action). The results of the questionnaire showed that the main factor hindering the commander's decision was uncertainty (77\%). In second place, officers identified a time deficit (73\%) and third place gave a suddenness (40\%). Danger (30\%), novelty (29\%) and increased pace of action (22\%) are, respectively, less significant stimuli in decision making.

Originality. A number of psychological factors exert a significant influence on the decision-making process of a commander in combat. The effects of these factors on the psychological stability of the commander in the decision-making process should not be reduced. In addition, it should be emphasized that the features of emotional shifts and their nature depend primarily on the intensity of these factors.

Conclusion. Having analyzed the most important psychological factors of combat that influence the decision-making process of a commander, we have identified the following factors: novelty, suddenness, uncertainty, danger, time deficit, increase in pace of action. Uncertainty is a major factor preventing the commander from deciding. The negative effect of these factors can be significantly reduced provided that systematic and importantly conscious work on mastering military and professional activity in the conditions of action of the simulated psychological factors of combat.

Further research into decision-making by commanders, we see in a detailed study of the main factor that adversely affects decision-making and constantly accompanies the commander - this is uncertainty.

Key words: commander; decision; psychological factors; vigilance; uncertainty; novelty; situation analysis; cognitive activity. 